\title{
Economic Impacts of Land Acquisition for Yogyakarta International Airport Project
}

\author{
${ }^{1}$ WESTI UTAMI, ${ }^{2}$ DIHIEN NURCAHYANTO, ${ }^{3}$ SUDIBYANUNG \\ ${ }^{123}$ Sekolah Tinggi Pertanahan Nasional, Jl. Tata Bumi No. 5 Gamping Sleman Yogyakarta, Indonesia, \\ email: ${ }^{1}$ westiutami@stpn.ac.id; ${ }^{2}$ dihien46@gmail.com ; ${ }^{3}$ nanung.sekar@gmail.com
}

\begin{abstract}
The study aims to analyze the economic impact of land acquisition for Yogyakarta International Airport project on the affected community. The research is conducted quantitatively, collecting data through questionnaires and data analysis techniques through descriptive statistics. Respondents are randomly selected as many as 45 households. The variables used include occupation, income, cost of living, and asset ownership. The results show that land acquisition has an impact on job losses of $15.6 \%$ and $8.9 \%$ of odd jobs, $35.6 \%$ decrease in income, $7 \%$ decrease in asset ownership and $15.5 \%$ increase in the cost of living. The results of the study show that land acquisition has a negative impact on the decline in the economic conditions of some affected communities. In this context, the restoration of community life should be an integral part of land acquisition projects.
\end{abstract}

Keywords: livelihood restoration, economic impacts, land acquisition.

\section{Introduction}

Yogyakarta International Airport (YIA) project, which covered an area of 587.04 $\mathrm{Ha}$ affecting \pm 2700 families, gave the best practice on land acquisition with large scale after the Law No. 2 of 2012 prevails (Kusuma, 2016; Mawadati \& Fajri, 2018). Despite the successful land acquisition and airport development, problems still occur up until now, especially the impacts of land acquisition on the lives of the community who lives in rural area (Sopanudin, 2016; Azizah, 2017).

Rural community, as one living unit with homogeneous types of jobs, whose lives depend on the production of agricultural land/sector as a means of main production makes most of the people work as farmers (Basrowi \& Juariyah, 2010). In this context, land acquisition for the airport which takes up part of the rural area causes changes in agricultural land and livelihood of the community as the area of rice fields (irrigation/rainfed), moorlands, and plantations affected by the project reach $54.83 \%$. The distribution of land use for YIA's land acquisition locations is presented in table 1.

Table 1

\begin{tabular}{clrr}
\multicolumn{4}{c}{$\begin{array}{c}\text { Land Use in Jangkaran, Sindutan, } \\
\text { Palihan, Glagah, Kebonrejo }\end{array}$} \\
\hline No & Type of Land Use & Area (Ha) & \multicolumn{1}{c}{$\%$} \\
\hline 1 & Embankment & 224,21 & 11,47 \\
2 & Moor & 337,68 & 17,27 \\
3 & Irigated Rice Field & 566,33 & 28,96 \\
4 & Sward & 4,86 & 0,25 \\
5 & Settlement & 504,55 & 25,80 \\
6 & Garden & 167,31 & 8,56 \\
7 & Rainfed Rice Field & 0,78 & 0,04 \\
8 & Sand & 85,70 & 4,39 \\
9 & River & 62,75 & 3,21 \\
10 & Sports Field & 1,15 & 0,06 \\
\hline \multicolumn{4}{c}{ Total } \\
\hline
\end{tabular}

Source: Kulon Progo Land Office

Received: November 22, 2020, Revision: April 01, 2021, Accepted: June 20, 2021

Print ISSN: 0215-8175; Online ISSN: 2303-2499. DOI: https://doi.org/10.29313/mimbar.v37i1.6955

Accredited Sinta 2 based on the decree No.10/E/KPT/2019 until 2024. Indexed by DOAJ, Sinta, Garuda, Crossreff, Dimensions 
Table 1 shows that agricultural land as the source of livelihood for many of people is affected by the project. It causes implications for the economic conditions of rural community who depends on the agricultural sector for their livelihoods. Various studies show that people who work in the small-scale agricultural sectors, farm workers, tenant farmers, or breeders will experience adverse impacts due to land acquisition (Ghatak, 2013; Kustiningsih, 2017). Therefore, an assessment of the economic impact on community affected by land acquisition needs to be carried out so that the government is able to implement appropriate recovery policies for the community.

Although Law No. 2 of 2012 states that compensation can be given in the form of money, land, and relocation or it can be realized in the form of shares, compensation in the form of money is mostly chosen as compensation for land that has been released from existing land acquisition, be it in Kulon Progo or several other locations. Compared to the other forms, this form is considered the easiest, most practical, and fastest. In fact, when it is seen from the economic point of view, the value of compensation in the form of land and settlements or shares are more profitable and are effective solution to make the people affected by land acquisition assured of their livelihoods, so that they can create a sustainable life (Zhang, 2011; Khatua \& Sarma, 2019).

Compensation in the form of land and settlements certainly makes it easy for the community to acquire land and resettlement, considering that the price of land after land acquisition increased significantly. As happened in Kulonprogo, investment and land purchases in the vicinity of land acquisition occurred since the airport was planned to be built around 2011/2012. Investors with large capital flocked to buy lands which has resulted in unhealthy land prices around the YIA construction. In this condition, the compensation money received by the community affected by land acquisition can no longer be used to buy new lands in the vicinity of the land acquisition location.

The value of compensation provided to the affected community in Kulonprogo varies greatly. People who owned large tracts of land in strategic locations got compensation that was far above the estimated price. However, people whose land was narrow and located far from the main road received very little. With these conditions, it can be said that land acquisition in Kulonprogo has made some people feel benefited, but farmers, fishermen, embankment workers, breeders, and tenant farmers who worked on the cultivated land of Pakualaman Ground feel disadvantaged. Some people whose jobs were farm workers feel very lost because they only got compensation for the plants/ objects on it. This is because the value of compensation received is very small and there is limited arable land which causes farm workers and tenant farmers lose their jobs. Besides, farmers whose large part of their rice fields are affected by land acquisition with a considerable compensation value have difficulty buying new rice fields, considering that the price of land is far above the value of compensation they received. The rice fields that are available and can be purchased by the community who received compensation are currently far away in another sub-district. This condition makes it difficult for people who previously worked as farmers/tenant farmers and farm workers to get their jobs back.

In this context, farmers, breeders, and farm workers are categorized as the most vulnerable parties due to the airport development/land acquisition (Camalin \& Setiawan, 2017: 350-360; Ren, 2017). Efforts to provide assistance and empowerment for the affected community have been attempted by PT Angkasa Pura, the Regional Government, CSR, and the Central Government, but the effectiveness of training, mentoring, and workforce distribution is still targeting young age group (20 - 40 years old) (Mawadati \& Fajri 2018, 783-797). Training/capital participation for groups of farmers/laborers over the age of 40 with limited skills/abilities and the availability of job vacancies that cannot accommodate this age group has resulted in the majority of the community not having regained decent jobs.

The economic impact after land acquisition as happened in Kulonprogo is one of the problems, especially in large-scale land acquisition projects that take up rural area (Zhang, 2011; Azizah, 2017; Goswami, 2019). Based on these problems, a study of the economic conditions of rural community affected by land acquisition for airport, especially for people who have experienced relocation/resettlement in Jangkaran Village, Palihan Village, Glagah Village, Kebonrejo 
Village, and Janten Village needs to be carried out.

\section{Research Methodology}

\section{Variables and Methods}

This research was conducted using a quantitative approach with descriptive statistical analysis to measure the economic conditions of the communities affected by land acquisition. The study was conducted on people who were directly affected by land acquisition in 5 villages with a population of 283 families, while the respondents were taken by simple random sampling. Because the population is more than 100 , the sample can be taken from 10-15\% (Arikunto 2010) and in this study the number of samples were 45 households (15\%) spread out in Jangkaran, Kebonrejo, Janten, Palihan and Glagah Village. The distribution of the population is presented in table 2 .

Table 2

\section{Resettlement Location, Population and} Sample

\begin{tabular}{llcrr}
\hline No & $\begin{array}{l}\text { Resettlement } \\
\text { Location }\end{array}$ & $\begin{array}{l}\text { Large } \\
(\mathrm{Ha})\end{array}$ & $\begin{array}{c}\text { Popula } \\
\text { tion }\end{array}$ & \multicolumn{2}{c}{$\begin{array}{l}\text { S a m } \\
\text { ple }\end{array}$} \\
\hline 1 & Jangkaran & 0,19 & 4 & 1 \\
2 & Kebonrejo & 1,00 & 24 & 5 \\
3 & Janten & 1,57 & 54 & 9 \\
4 & Palihan & 2,76 & 99 & 15 \\
5 & Glagah & 4,21 & 102 & 15 \\
\hline
\end{tabular}

In this study, the variables used to measure the economic condition of the community include employment, income level, cost of living, and asset ownership.

\section{Instruments of Research}

Data collection on the communities affected by land acquisition was carried out through a questionnaire with a "closed answer" option according to the research instrument. The answer is determined using a Likert scale approach, namely the value of " 1 " for the criterion of "experiencing a very bad economic impact" and a value of " 5 " for the criterion of "experiencing a very good economic impact". The research instrument was determined based on the previous survey literature. The data from the questionnaire was then processed through descriptive statistical techniques, so that it could present the grouping of maximum values, minimum values, and average values. The results of

\begin{tabular}{llrrr}
\hline No & Type & $\begin{array}{l}\text { Area } \\
\text { (Ha) }\end{array}$ & $\begin{array}{l}\text { Compensation } \\
\text { Value }\end{array}$ & \multicolumn{2}{l}{$\%$} \\
\hline $\mathbf{1}$ & $\begin{array}{l}\text { Private- } \\
\text { owned Land }\end{array}$ & 357,25 & 2.769 .935 .288 .819 & $60.86 \%$ \\
\hline $\mathbf{2}$ & $\begin{array}{l}\text { Private- } \\
\text { owned Land }\end{array}$ & 37,38 & 262.882 .426 .242 & $6,375 \%$ \\
\hline 3 & $\begin{array}{l}\text { Pakualaman } \\
\text { Ground } \\
\text { (PAG) }\end{array}$ & 160,30 & 701.512 .349 .000 & $27,30 \%$ \\
\hline $\mathbf{4}$ & Agency Land & 31,65 & 292.542 .159 .214 & $5,39 \%$ \\
\hline $\mathbf{5}$ & $\begin{array}{l}\text { PAG } \\
\text { Cultivator }\end{array}$ & - & 72.135 .320 .135 & - \\
\hline $\mathbf{6}$ & $\begin{array}{l}\text { Residual } \\
\text { Land }\end{array}$ & 0.18 & 1.319 .807 .040 & $0,03 \%$ \\
\hline $\mathbf{7}$ & Waqf Land & 0.28 & 4.406 .513 .000 & $0,05 \%$ \\
\hline $\mathbf{8}$ & $\begin{array}{l}\text { Discretionary } \\
\text { Land }\end{array}$ & - & 19.960 .740 .250 & - \\
\hline & Total & 587,04 & $4.124 .694 .603,700$ & $100 \%$ \\
\hline
\end{tabular}

this data grouping then become the basis for describing the economic conditions of the community affected by land acquisition. The research flow diagram is presented in figure 1.

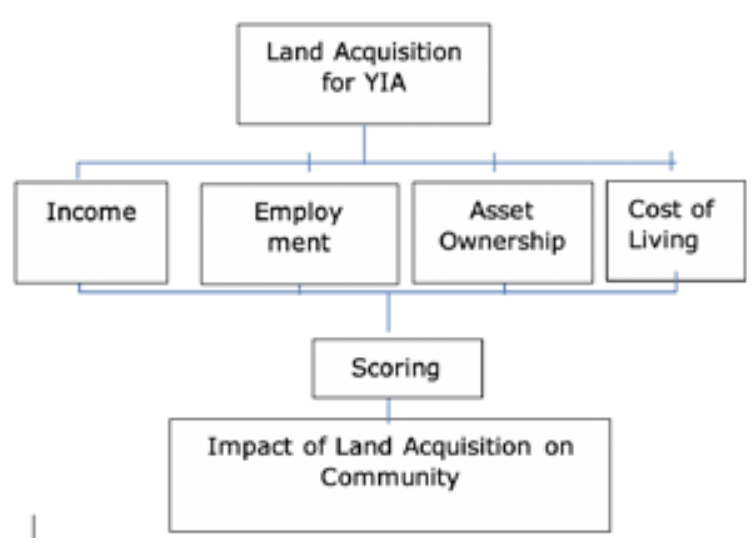

Figure 1. Research Flow Diagram

In this study, the researchers also conducted field observations and interviews to determine the condition of the community after the construction of YIA. Interviews were conducted with Head of Palihan Village, Head of Glagah Village, Local Government (Public Works and Public Housing Agency), and the affected community.

\section{Results and Discussion}

\section{Resettlement of The Affected Community in Kulonprogo}

The acquisition of land with an area of $587.04 \mathrm{Ha}$, took up at least private-owned land, village land, agency land, waqf land, and also Pakualaman Ground land with a total of $\pm 3,942$ land parcels (Goldie 2018, 198 - 225). The details of land tenure and ownership for the construction of YIA are presented in table 3 below. 
MIMBAR, Vol. 37, No. $1^{\text {st }}$ (June, 2021), pp. 150-160

Table 3

Tenure/Ownership of Land Affected by Land Acquisition of YIA

\begin{tabular}{lllll}
\hline No & Type & Area $(\mathrm{Ha})$ & Compensation Value & $\%$ \\
\hline 1 & Private-owned Land & 357,25 & 2.769 .935 .288 .819 & $60.86 \%$ \\
2 & Private-owned Land & 37,38 & 262.882 .426 .242 & $6,375 \%$ \\
3 & Pakualaman Ground (PAG) & 160,30 & 701.512 .349 .000 & $27,30 \%$ \\
4 & Agency Land & 31,65 & 292.542 .159 .214 & $5,39 \%$ \\
5 & PAG Cultivator & - & 72.135 .320 .135 & - \\
6 & Residual Land & 0.18 & 1.319 .807 .040 & $0,03 \%$ \\
7 & Waqf Land & 0.28 & 4.406 .513 .000 & $0,05 \%$ \\
8 & Discretionary Land & - & 19.960 .740 .250 & - \\
\hline \multicolumn{2}{r}{ Total } & 587,04 & $4.124 .694 .603,700$ & $100 \%$ \\
\hline
\end{tabular}

Source: Laporan Hasil Pengadaan Tanah PT Angkasa Pura/PT Angkasa Pura Land Acquisition Report

The compensation mechanism for land acquisition in the form of resettlement is one of the compensation mechanisms which is considered more beneficial for the affected community. This is because the price of land around the airport has increased significantly after land acquisition. Given these conditions, the desire of the affected community in Kulonprogo to get resettlement is a solution so that people can have a settlement whose locations are not far from their previous places. The hope is that with the resettlement around the airport, the people who previously worked around the land acquisition location will have easier access to the work location, make it easier for the community to adapt to the new environment, and psychologically they have a strong emotional bond with the surrounding land/community so that the displacement provides comfort for the affected community. In addition, by moving not too far from the airport, the community hopes to develop businesses/services (catering, transportation, or accommodation related to airport services) to ensure their livelihoods. Resettlement for the affected community is certainly one of the effective efforts so that people have easy access in terms of the availability of road networks, transportation facilities, and the availability of public facilities/other social facilities that support livelihood sustainability.

Lands for relocation sites for the affected community are located around the airport, where parts of the lands used are village lands. This land selection mechanism is considered to be more effective and efficient because some village lands have large land availability. The process of providing lands from village lands is relatively easy, so it can accelerate the process of providing lands for resettlement. The community obtained the village land that has been used through a buying and selling process at a price of land according to a fair figure, which was in the range of approximately IDR500,000/m (Interview with Head of Palihan Village 2020). The locations used for resettlement for the affected community are in 5 villages, namely Palihan Village, Jangkaran Village, Glagah Village, Kebonrejo Village, and Janten Village (Interview with Public Works and Public Housing Agency 2020). These five villages are used for resettlement because the people affected by land acquisition are in these five villages. Resettlement which was carried out in the same community and village was intended so that the community does not experience difficulties in dealing with civil administration and to provide facilities for the community to adapt to the new residential environment.

\section{Economic Condition of the Affected Community}

After the land acquisition and construction of the Yogyakarta International Airport, most of the affected people reside in relocation places where the provision of lands was facilitated by the government. The economic and life conditions of the people living around the airport at the 5 resettlement locations are quite diverse. The results of the analysis carried out on 45 respondents using the variables of jobs, income, cost of living, and asset ownership to determine the economic condition of the community are presented as follows. 


\section{Working Conditions of the Affected Community}

Land acquisition that occurs in several regions in Indonesia often results in major problems in the form of non-continuation of work/loss of jobs for the communities. Likewise in various other countries such as in Tanzania in a study by Kusiluka (2011), in Ghana in a study by Mabe (2019), and in Zimbabwe (Thondhlana, 2015) stated that land acquisition has a negative impact on the loss of community livelihoods. Another study reinforced by Nanhthavong (2021) states that land acquisition in Lao PDR has an impact on decreasing the level of community welfare. This condition also occurs in land acquisition after the construction of YIA. The results of a survey conducted at 5 resettlement locations with 45 respondents show the following data.

Figure 2 shows that prior to land acquisition, most of the people in the five villages, as many as $51.1 \%$, worked as farmers, while $24 \%$ relied their livelihoods on agriculture as agricultural laborers, and $5 \%$ made their living from aquaculture and livestock. These results indicate that the total number of respondents who depended on natural resources, especially land/ agricultural land, is $80 \%$. This condition indicates that the homogeneity of work is dominated by the agricultural sector, which of course occupies a high level of vulnerability if exposed to land acquisition. This condition is based on the studies of the researchers (Zhang, 2011; Wilmsen, 2016; Kustiningsih, 2017; Goswami, 2019) and facts on the field that show that vulnerable groups in land acquisition often experience adverse impacts of land acquisition. The handling of the vulnerability of the community should have been mapped from the beginning during

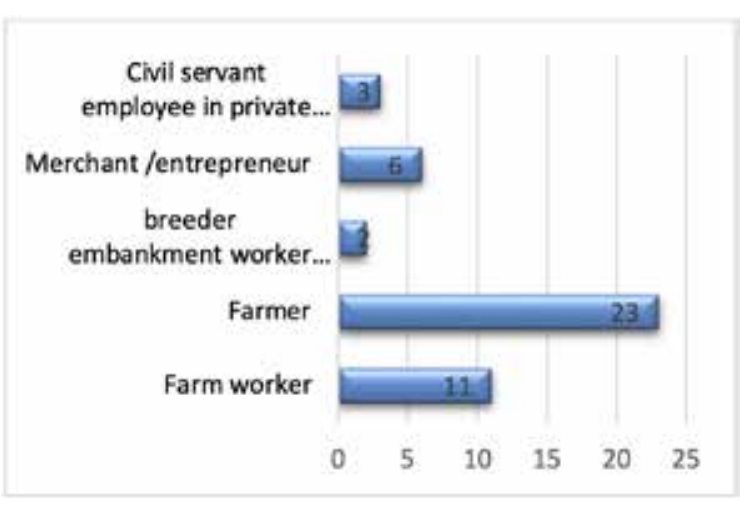

Figure 2. Respondents' Jobs before Land Acquisition

(Data Analysis 2020)

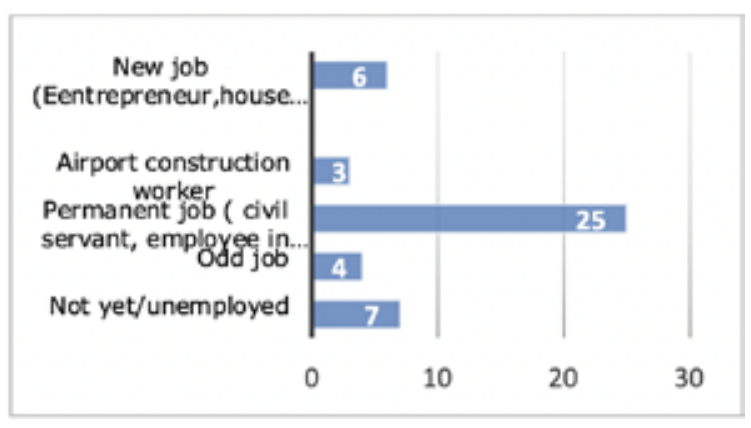

Figure 3. Jobs after Land Acquisition

the preparation stage by those who need land. With this, it is hoped that those who need land and the land acquisition team can formulate appropriate policies for vulnerable groups when land acquisition is carried out in certain locations.

Furthermore, the analysis results show that the work condition of the respondents after land acquisition is as in the figure 3.

From the two tables, it can be seen that prior to land acquisition, all respondents had jobs either as farmers/farm worker/ breeders/ entrepreneurs or as civil servants, however after land acquisition caused 15\% of respondents to lose their jobs and up to the time this research was conducted, they were still unemployed. In the analysis of the people who have not worked, it was found that they were previously agricultural laborers, tenant farmers, and breeders/ embankment workers. Meanwhile, there are also respondents who do odd jobs $(9 \%)$, meaning that they do not have permanent jobs. When classified, they fall into the vulnerable group. From the survey conducted, there are also $7 \%$ of respondents who got new jobs, which are those involved in airport project construction. In the future, the fate of the $7 \%$ of the people involved in the construction of this project is still questionable, which means that when the airport construction is completed, their future jobs are still uncertain. In this case, it can be said that land acquisition for the construction of Yogyakarta airport brought changes to at least $31 \%$ of respondents as affected people who, when viewed from the work sector, are in a vulnerable condition.

Land acquisition has changed 45 respondents who previously had jobs to only 25 respondents or $55 \%$ of the affected people working with permanent jobs. These results indicate that when land acquisition took up agricultural land while most people depended on the agricultural sector, the bad 
impact that occurs is that they have difficulty in finding new jobs. This condition can make it difficult for people to return to a life that is at least the same as before, now even far from their hopes of getting a better, sustainable life. This study was carried out 1 year after the community received compensation for the land they had released. In a period of 1 to 3 years, perhaps, the community can still survive with the compensation they received (this of course depends on the amount of money received). However, if this condition continues, where people do not immediately get decent jobs to meet their daily needs, the community's condition will gradually decline and poverty can arise.

The results of the analysis and interviews show that a small proportion of respondents (13\%) who received quite large compensation, invested their money in the form of land, deposits or buildings for rent. They do this scheme to secure their money and the deposit interest can be taken to support their survival. It can be said that the people who choose this option, who depend on deposit interest, get income, but when viewed from the work sector, they have not been able to get permanent jobs to create a sustainable life. The changing conditions of the respondents' jobs affected by land acquisition are presented in figure 4 .

\section{Sustainability of Community's Income}

People's income is influenced by several factors, one of which is related to the jobs they do for living. In this study, the income level is calculated from the total income in a family, not the income of each respondent. The results of the study show that the level of income of the people in Kulonprogo varies: some increased, but some stagnated, and some even decreased. The distribution of

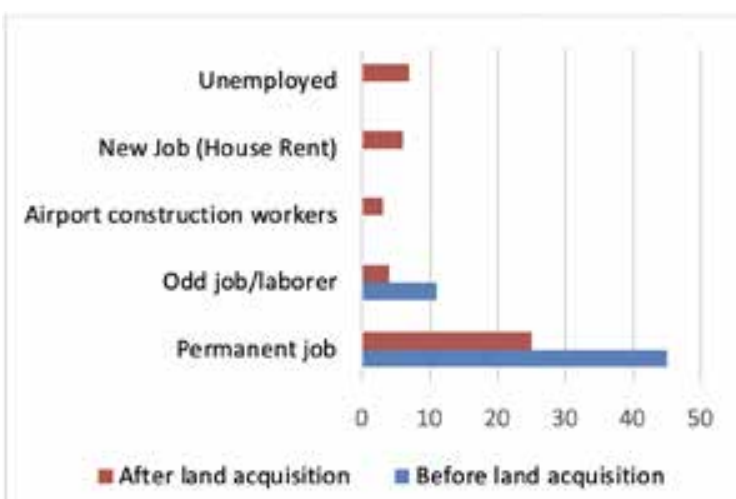

Figure 4. The Change of Respondents' Job respondents' income levels is presented in figure 5 below.

Based on the results of the study obtained, the increase in the amount of community income experienced by $42 \%$ of respondents is due to the fact that, when the research was carried out, the community still enjoys quite a lot of deposits from compensation money they received. This condition certainly cannot last for a long time if the community has not found permanent jobs. Several other factors, which emerged when the research was conducted and had an effect on the increase in respondents' income, were that some respondents are able to rent out houses for workers who are building airport projects; some others sell foods/drinks for airport project workers; there are also people who work with the contract system on airport construction project. However, this condition is not necessarily stable and sustainable.

Land acquisition provides benefits for people who receive a large amount of compensation, so that their income increases. However, this condition certainly requires good financial management and assistance so that the money received by the community is able to create and guarantee a sustainable life. Compensation in the form of money received by the community should not be spent on goods that are only consumptive in nature, but should be allocated for business or the purchase of assets that can guarantee the life of the community in the future.

Problems that arise after land acquisition in various cases as happened in Gana (Korah et.al, 2019); Vietnam (Ngunyen \& Kim, 2020); and China (Yin et.al, 2020) cause the community to experience a decrease in income, likewise in this study in

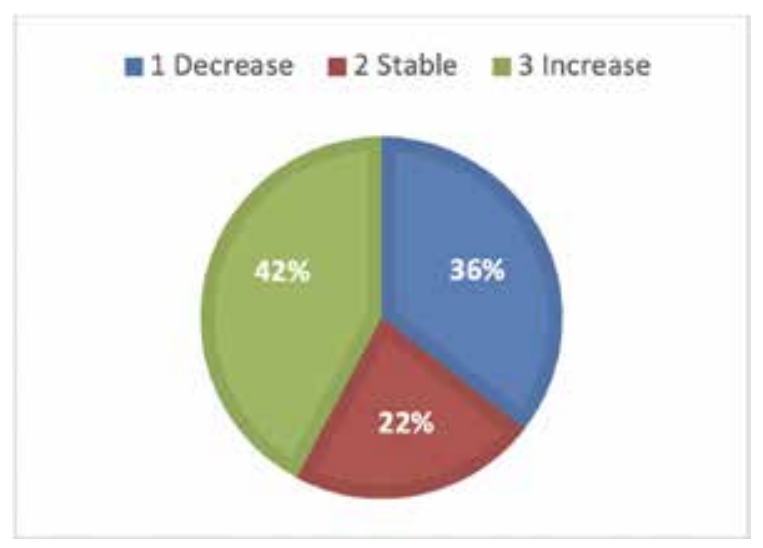

Figure 5. Level of Community's Income after Land Acquisition 
which $36 \%$ of the affected people experience a decline in income. This condition is influenced by the presence of respondents who have not found jobs/are unemployed and work on odd jobs with uncertain income. This kind of community condition certainly requires solutions or policies from the government or other stakeholders so that vulnerable communities (farmers, breeders, farm workers) who previously worked by depending on agricultural land can get jobs that are, at least, the same as before land acquisition occurred or new jobs that are suitable with their ages, skills and experience.

\section{Living cost Conditions of Affected Communities}

Results of the survey of 45 respondents indicates that the level of living cost of most respondents has increased. The first factor affecting the living cost is the increased monthly electricity costs. In addition, the increase in public living cost is influenced by the daily needs of the community that must be purchased. Prior to land acquisition, most of the community owned lands that could be used for growing vegetables/herbs and lands that could be used for raising animals as a source of family protein intake, which would certainly save the community's daily expenses (interview with the Head of Glagah Village in 2020). They lived in rural areas that were rich in food sources since every house had a garden where they could plant various productive crops that generate money (bananas, coconuts, fruits, and vegetables). In this context, the physical form of lands owned by the community was not merely land; the land they owned was intangible (Suriandi \& Hakim 2013), so that it was able to provide benefits and support life. Data on changes in community's living cost are presented in table 4.

Table 4

Comparison of Respondents' Living cost before and after Land Acquisition

\begin{tabular}{lllll}
\hline \multicolumn{2}{c}{ Before Relocation } & \multicolumn{3}{c}{$\begin{array}{l}\text { After Reloca- } \\
\text { tion }\end{array}$} \\
\hline Living cost & $\begin{array}{l}\text { Respon- } \\
\text { dent }\end{array}$ & $\%$ & $\begin{array}{l}\text { Respon- } \\
\text { dent }\end{array}$ & $\%)$ \\
ZIDR & 2 & 4,4 & 5 & 11,1
\end{tabular}

\begin{tabular}{|c|c|c|c|c|}
\hline $\begin{array}{l}\text { IDR } \\
2.500 .001- \\
\text { IDR } \\
\quad 3.500 .000\end{array}$ & 6 & 13,3 & 6 & 13,3 \\
\hline $\begin{array}{l}\text { IDR } \\
1.500 .001 \\
- \text { IDR } \\
2.500 .000\end{array}$ & 7 & 15,6 & 11 & 24,4 \\
\hline $1.500 .000 \geq$ & 30 & 66,7 & 23 & 51,1 \\
\hline
\end{tabular}

Source: Data Analysis, 2020

The results of the study indicate that although some of the community $(42.2 \%)$ experienced an increase of income after land acquisition, their living cost also increases due to a change of living conditions. Before land acquisition, the community could use their land to help fulfill their daily lives, but when they had to move to a new settlement location with narrow land conditions, they have to buy everything to meet their daily needs.

\section{Asset Ownership}

Asset ownership is one of the variables used to measure the economic condition of the community after land acquisition. The assets referred to in this study include movable property (cars, motorbikes, bicycles, electronic goods, jewelry/gold bars, etc.) and immovable property (land, houses, boarding houses, etc.). The results of the analysis show that, after land acquisition, most of the community, or $53.3 \%$ of the respondents, has assets or the same as before. This indicates that the compensation money for land acquisition owned by the community is realized again with the same properties. This means that if before the land acquisition people owned lands with houses on them, then after the land acquisition the compensation money is only enough to buy lands and build new settlements for their families. The survey results also show that $7 \%$ of respondents experiences a decrease in asset ownership. This condition occurs in people who received a small compensation value which is generally experienced by farm workers or tenant farmers at Pakualaman Ground, so that the compensation value is not sufficient to buy properties that are the same as what they owned before land acquisition. The distribution of data on the level of respondents' asset ownership is presented in table 5 . 
Table 5

Level of Asset Ownership

\begin{tabular}{cclrr}
\hline No & $\begin{array}{c}\text { Asset } \\
\text { Owner- } \\
\text { ship Value }\end{array}$ & $\begin{array}{c}\text { Cate- } \\
\text { gory }\end{array}$ & $\begin{array}{r}\text { Re- } \\
\text { spon- } \\
\text { dent }\end{array}$ & (\%) \\
\hline 1 & $7-13$ & Low & 3 & 6,7 \\
2 & $14-20$ & Fair & 24 & 53,3 \\
3 & $21-27$ & High & 18 & 40,0 \\
& Total & & $\mathbf{4 5}$ & $\mathbf{1 0 0 , 0}$ \\
\hline
\end{tabular}

Source: Data Analysis 2020

\section{Restoration of life for communities affected by land acquisition in rural areas}

From several studies conducted, it is found that, so far, some land acquisition practices in Indonesia focused more on how land acquisition could be carried out and how land acquisition could be obtained immediately through the compensation process (Azizah, 2017; Swela, 2017). However, studies regarding the conditions of the affected communities after land acquisition, the sustainability of the life of the community, and the resettlement of the affected community have not received much attention from the government or from those who need land. The lack of government attention to this condition in a study by Ghatak (2011); De (2016); Karmakar (2017); Khatua \& Sharma (2019) can certainly be a big problem that can threaten the socio-economic life of the community and can lead to poverty for the affected community. Several practices show that the conditions often occur after compensation payments are made are that the parties who need the land seem to be hands off of what will happen to the lives of the affected community in the future.

Even though Law No.2 of 2012 has explained that in land acquisition there are at least the principles of sustainability and welfare both for the community as a whole and for the affected community/entitled parties (Subekti 2016; Muliawan 2018), in practice, the objectives of these principles have not been able to be wholly realized. In the context of land acquisition in Kulonprogo, policies and compensation that have been implemented have been able to provide better welfare and sustainability of life for some people. However, land acquisition also makes the affected community bear heavy consequences: loss of jobs and decrease of income.

From this study, it is found that people who are able to realize a sustainable life and increase their welfare are 1) people who received compensation money in sufficient quantity so that they are able to create or continue jobs from the capital they have; 2) people who have permanent jobs (civil servants/employees in private sectors/ merchants/entrepreneurs) who do not depend on natural resources in the form of land; 3) people who have certain skills, age, and physical conditions, so that they can work in sectors related to YIA's development and operations (ex: airport security guards, counter guards, cleaning service, porters, etc.). However, this condition is in contrast to the community, which until the time the research was carried out has not been able to obtain an increase in welfare or life sustainability. Tenant farmers, embankment workers, farm laborers, fishermen, and breeders (vulnerable groups) who depended on agriculture/land for their livelihoods have difficulty finding suitable jobs. Age that is no longer productive, limited skills, and habits of people of depending on agricultural land make them unable to obtain a life that is at least the same, or even better than before land acquisition, as mandated in Law No. 2 of 2012. Research conducted by McCharty (2012) states that people who depend on the agricultural sector, the narrower cultivated land they seek will be directly proportional to the level of income they earn, this condition also occurs in the study area.

As research conducted by McCharty (2012) states that people who depend on the agricultural sector, the narrower the arable land they work on will be directly proportional to the level of income they get. Various studies and theories on rural development also state that the recovery and improvement of the living standards of rural communities is often hampered due to low income levels, limited creativity and limited capital, especially land (Kakisina 2011; Ibrahim et al 2016). With the loss of land or the reduction of land because it is used for the construction of airports and other supporting infrastructure, rural communities are increasingly vulnerable.

Monitoring and evaluation efforts on the implementation of land acquisition should be implemented and regulated through binding regulations so that the affected communities, especially those in 
vulnerable group, do not experience adverse impacts when the government/parties who need land carry out land acquisition (Jiao et al. 2017; Perera 2014; Khedrigharibvand et.al 2019). The policy for resettlement and efforts to restore the lives of the affected communities to become an integral part of the land acquisition program has become a demand, considering that land acquisition often has negative impacts on the people who depend on the agricultural sector for their livelihoods. The concept and obligation to build resettlement and restore community life in land acquisition have been regulated in international standards applied to the Asian development bank and the world bank. And Indonesia should be able to implement this concept so that risk mitigation can be carried out for affected communities (Atahar, 2013; International Councilon Mining \& Metals 2019).

Broadly speaking, land acquisition in Kulonprogo can be said to be quite successful where every stage was carried out well; compensation money given to some people was also more profitable; community assistance and empowerment activities were also carried out. However, what the government and those who need the land have done has left problems for those in vulnerable group who have yet to find jobs. In this context, a strategy for restoring people's lives based on socio-economic data and involving community participation is something that must be done in land acquisition (Perera 2014). Monitoring and evaluation also need to be done to ensure that the community is able to get a better life after land acquisition.

\section{Conclusions}

This paper argues that post land acquisition has a negative impact on decreasing community income, loss of jobs or increasing unemployment, decreasing ownership of community assets and increasing costs of living which are increasingly burdensome for the community. Most of the residents affected by YIA airport are people who depend on the agricultural sector (farmers, ranchers, laborers and smallholders), which in several studies show that this community is included in the vulnerable group. The strategy for restoring people's lives that is still limited, unsustainable and the absence of monitoring of community life after land acquisition have contributed to post-land acquisition problems for the community. This condition should be addressed by agencies requiring land and related stakeholders in order to formulate a mitigation strategy for land acquisition risk reduction. Resettlement efforts and restoration of community life as an integral part of the land acquisition program need to be formulated in comprehensive and binding regulations so that the community can have a sustainable life.

\section{Acknowledgment}

This article is written based on data obtained from the study of the first author and partly taken from the research data of the second author. The author would like to thank the respondents as the community affected by land acquisition in Kulonprogo and those who have helped in the research.

\section{References}

Arikunto, S. (2010). "Prosedur Penelitian Suatu Pendekatan Praktek", Jakarta: Rineka.

Atahar, S.A. (2013). Development Project, Land Acquisition and Resettlement in Bangladesh; A Quest for Well Formulated National Resettlement and Rehabilitation Policy. International Journal of Humanities and Social Science, Vol. 3, No. 7.

Azizah, N. (2017). Dampak Sosial Ekonomi Pembebasan Lahan Pembangunan Bandar Udara (New Yogyakarta International Airport) (Studi Kasus Kecamatan Temon, Kabupaten Kulon Progo, Daerah Istimewa Yogyakarta). Jurnal IImu Politik, Vol.8 No.2.

Basrowi \& Juariyah, S. (2010). Analisis Kondisi Sosial Ekonomi dan Tingkat Pendidikan Masyarakat Desa Srigading, Kecamatan Labuhan Maringgai, Kabupaten Lampung Timur. Jurnal Ekonomi \& Pendidikan, Vol. 7, No. 1.

Camalin, M., Setiawan, I. (2017). The Role of Women Farmer Group in Increasing Family Welfare, Mimbar, 33 (2), 350360.

De, D. (2016). Whose Land is it Anyway? Property, Law and Rights in the Land Acquisition Question in India, Journal of Land and Rural Studies, 4(1), pp. 23-35, Centre for Rural Studies, LBSNAA SAGE Publications sagepub.in/home.nav DOI: $10.1177 / 2321024915616670 \mathrm{http}: / /$ Irs. sagepub.com. 
Ghatak, M. \& Mookherjee, D. (2013). Land Acquisition for Industrialization and Compensation of Displaced Farmers, Journal of Development Economics, pp 303-312, http://dx.doi.org/10.1016/j. jdeveco.2013.01.001, Journal homepage: www.elsevier.com/ locate/ devec

Goldie, J. (2018). Pihak yang Berhak Mendapat Ganti Kerugianan dalam Pengadaan Tanah bagi Pembangunan untuk Kepentingan Umum di Atas Tanah Pakualam. Jurist-Diction Jurnal, vol. 1.

Goswami, S. (2019). Land Acquisition and Involuntary Displacement: A Study of Changing State Society Relations, 10 (3), Published in the Russian Federation European Researcher. DOI: 10.13187/ er.2019.3.148

Government Regulation of the Republic of Indonesia Number 19 of 2021 concerning Implementation of Land Procurement and Development for Public Interest

Ibrahim, Baiquni, M., Ritohardoyo, S., Setiadi, (2016). Characteristics of Poverty in Rural Communities of Gold Mining District Area West Sumbawa, Mimbar, 32 (1), 163-174.

International Councilon Mining \& Metals (2019). Land Acquisition and Resettlement: Lesson learned, ICMM Portman Square London W1H6LR, United Kingdom.

Jiao, X., Pouliot, Marieve, \& Walelign, S. Z. (2017). Livelihood Strategies and Dynamics in Rural Cambodia. World Development, 97, 266-278. https://doi. org/10.1016/j.worlddev.2017.04.019

Kakisina, O. Leunard. (2011). Analisis Tingkat Pendapatan Rumah Tangga dan Kemiskinan di Daerah Transmigrasi (Kasus di Desa Waihatu, Kecamatan Kairatu, Kabupaten Seram Bagian Barat, Provinsi Maluku), Jurnal Budidaya Pertanian, 7 (2), 65-71.

Karmakar, P. (2017). 'Politics of Development: Land Acquisition and Economic Development in India', Journal of Land and Rural Studies, 5(2), pp. 164-182, Centre for Rural Studies, LBSNAA SAGE Publications sagepub.in/home.nav DOI: $10.1177 / 2321024917703848$ http://Irs. sagepub.com

Khatua, S., Sarma, V. (2019). Short Term Versus Long Term Effects of Forced Displacement, Edited by Yoshino, N, Paul, S, Land Acquisition In Asia Towards $A$ Sustainable Policy Framework, Palgrave macmillan.
Khedrigharibvand, H., Azadi1, H., Teklemariam, D., Houshyar, E., Maeyer, P.D., Witlox, F. (2019). Livelihood Alternatives Model for Sustainable Rangeland Management: A Review of Multi-Criteria Decision-Making Techniques, Environment, Development and Sustainability, 21, 11-36, https:// doi.org/10.1007/s10668-017-0035-5.

Korah, P.I, Nunbogu, A.M., Cobbinah, P.B., Akanbapang, B.A.A. (2019), Analysis of Livelihood Issues in Resettlement Mining Communities in Ghana, Resources Policy, 63, https://doi.org/10.1016/j. resourpol.2019.101431.

Kusiluka, M.M., Kongela, S., Kusiluka, M.A., Karimuribo, E.D., Lughano, Kusiluka, M.J.M.(2011).TheNegativeImpactOfLand Acquisition On Indigenous Communities' Livelihood And Environment In Tanzania, Habitat International 35 (2011) 66e73, doi: 10.1016/j.habitatint.2010.03.001.

Kustiningsih, W. (2017). Kelompok rentan dalam pembangunan kawasan Kota Bandara di Kulonprogo Studi Kasus New Yogyakarta International Airport (NYIA), Jurnal Pemikiran Sosiologi, Vol. 4, No.1.

Kusuma, H.A. (2016). Penetapan Bentuk Ganti Kekerugian dalam Pengadaan Tanah Untuk Pembangunan Bandara di Kulon Progo sebagai Upaya Mewujudkan Perlindungan Hukum. Jurnal Ilmiah Universitas Atma Jaya.

Laporan Hasil Pengadaan Tanah PT. Angkasa Pura ( $P T$ Angkasa Pura Land Acquisition Report), Ppt diperoleh saat kegiatan studi lapang pelatihan pengadaan tanah, Kerjasama STPN-UGM dan World Bank

Law Number 2 of 2012 concerning Land Procurement for Public Interest.

Law Number 11 of 2020 concerning Job Creation

Mabe, F.N., Nashirub, S., Mummunic, E., Boateng, V.F. (2019), The Nexus Between Land Acquisition and Household Livelihoods in the Northern Region of Ghana, Land Use Policy,85, 357-367, https://doi.org/10.1016/j. landusepol.2019.03.043

Mawadati, S., \& Fajri, C. (2018). Manajemen Krisis Pemerintah Kabupaten Kulon Progo, Jurnal Aspikom, Vol. 3, No.4, pp. 783-797.

McCharty, J.F., Vel, J.A.C., Afiff, S. (2012). Trajectories of Land Acquisition and Enclosure: Development Schemes, Virtual Land Grabs, and Green Acquisitions in Indonesia's Outer Islands, 39 (2), https://doi.org.ezproxy.ugm.ac. 
id/10.1080/03066150.2012.671768

Muliawan, J.W. (2018). Cara Mudah Pahami Pengadaan Tanah untuk Pembangunan Melalui Konsep 3 In 1 In The Land Acquisition. Jurnal Hukum Peratun, Vol. 1, No. 2, pp. 163-182.

Nanhthavong, V., Oberlack, C., Hett, C., Messerli, P., Epprecht, M. (2021), Pathways to Human Well-Being in the Context of Land Acquisitions in Lao PDR, Global Environmental Change, 68, https://doi. org/10.1016/j.gloenvcha.2021.102252

Ngunyen, Q, Kim, DC. (2020). Reconsidering Rural Land Use and Livelihood Transition Under The Pressure of Urbanization in Vietnam: A Case Study of Hanoi. Land Use Policy, 99, https://doi.org/10.1016/j. landusepol.2020.104896.

Perera, J. (2014). Displacement-ind, uced Impoverishment: The Role of a Sustainable Income Restoration and Improvement Strategy in Livelihood Rehabilitation in Sri Lanka, Council for Social Development, SAGE Publications, https://doi.org.ezproxy.ugm.ac.id/10.11 77\%2F0049085714536803

Ren, X. (2017). Land Acquisition, Rural Protests, and The Local State In China And India, Environment And Planning C: Politics And Space, Vol. 35(1), pp. 2541, Reprints and permissions: sagepub. co.uk/journalsPermissions.nav DOI: $10.1177 / 0263774 \times 16655802$, journals. sagepub.com/home/epc

Sopanudin, A. (2016). Konflik Lahan Pertanian dalam Pembangunan Bandara Internasional di Kulon Progo. Jurnal Skripsi, Fakultas IImu Sosial UNY.

Subekti, R. (2016). Kebijakan Pemberian Ganti Kerugian dalam Pengadaan Tanah Bagi Pembangunan untuk Kepentingan Umum. Jurnal Yustisia, Vol.5, No. 2.

Suriandi, A., Hakim, A. (2013). Alternatif Dasar Perhitungan Nilai Tanah untuk Pembangunan Waduk, Jurnal Sosial Pekerjaan Umum, Vol. 5, No. 2, pp. 76139.

Swela, A.G. (2017). Analisis Dampak Pembebasan Tanah dan Nilai Ganti Rugi Terhadap Kondisi Sosial Ekonomi Masyarakat Dalam Pembangunan Waduk Logung di Desa Kandangmas dan Desa Tanjungrejo Kabupaten Kudus. Journal of Politic and Government Studies, Vol. 6, No. 2.

Thondhlana, G. (2015), Land Acquisition and Local Livelihood Implications of Biofuel Development in Zimbabwe, Land Use Policy, 49, 11-19, https://doi. org/10.1016/j.landusepol.2015.06.025

Wilmsen, B. (2016). After the Deluge: A Longitunal Study of Resettlement at the Three Gorges Dam, Cina, World Development, Elsevier, 84@), 41-54

Yin, S., Yang, X., Chen, J. (2020). Adaptive behavior of farmers' livelihoods in the context of human-environment system changes, Habitat International, 100, https://doi.org/10.1016/j. habitatint.2020.102185

Zhang, C. (2011). Technical Note 1, Overview of Land Policies and Resettlement Practices in Rural Areas of China, Involuntary Resettlement in China, China and Mongolia Sustainable Development Unit World Bank Office in Beijing, East Asia Pacific Region, World Bank. 